Int. Agrophys., 2021, 35, 97-105

\title{
Changes to the physical properties of the soil after the passage of an agricultural tractor**
}

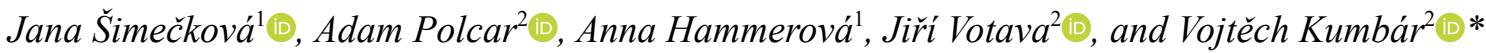 \\ ${ }^{1}$ Department of Agrochemistry, Soil Science, Microbiology and Plant Nutrition, \\ ${ }^{2}$ Department of Technology and Automobile Transport, \\ Faculty of AgriSciences, Mendel University in Brno, Zemědělská 1, 61300 Brno, Czech Republic
}

Received January 4, 2021; accepted February 28, 2021

\begin{abstract}
The effect of the passage of agricultural machinery on the soil is influenced by, for example, the inflation pressure in tyres. This article describes the effect of different tyre inflation pressures (200 and $100 \mathrm{kPa}$ ) on selected physical soil properties in the field experiment. The undisturbed samples were collected both in and between the tracks at depths of 0 to $0.5 \mathrm{~m}$ and subsequently processed according to a valid methodology in the laboratory. The results indicate that fewer negative changes were found in the variant with a lower inflation pressure for all of the observed soil properties (front wheels load $2990 \mathrm{~kg}$ and rear wheels $11760 \mathrm{~kg}$ ). However, the differences between the pressures were not statistically significant. The impact of different tyre pressures at greater depths has also not been proven to date. This may be attributed to the creation of a plough pan due to the long-term use of the minimization technique because the values of individual properties were balanced at a depth of 0.2 to $0.3 \mathrm{~m}$. These depths do not react to further tractor compaction due to the accumulation of compaction. Changes to the values of soil physical properties caused by the passage of the tractor were statistically significant for both tyre pressure variants only at depths ranging from 0 to $0.1 \mathrm{~m}$.
\end{abstract}

Keywords: soil compaction, tyre inflation pressure, physical properties

\section{INTRODUCTION}

Modern agriculture is dependent on vehicular traffic (soil processing, sowing, the application of fertilizers, pesticides and herbicides, as well as harvesting). Over the years, due to the development of technical knowledge, new materials and the need for financial savings, new machines

*Corresponding author e-mail: vojtech.kumbar@mendelu.cz

**This work was supported by the project ZETOR (EG15 019/0004799 - ZETOR TRACTORS a.s.) - Optimal aggregation of machines with a tractor (from 01.06.2017 to 31.08.2019). have been designed and built, they are larger and therefore heavier (Yahya et al., 2015). The original vehicle weight of about $3 \mathrm{t}$ at the beginning of the tractor era which includes other agricultural machinery from the 1940s has increased to more than $20 \mathrm{t}$ (Keller et al., 2019). This contributes to the destruction of the physical properties of the soil and leads to the formation of soil compaction (Raper, 2005).

The adverse effect of compaction has had a deleterious influence on other components of the environment. The agronomic treatment of compacted soil requires a higher level of fuel consumption, especially during ploughing. A higher level of fuel consumption, moreover, leads to the production of more greenhouse gases (Tullberg, 2010). The soil's ecological functions which are ensured by the pore system are also damaged. The infiltration rate decreases, the supply of soil water wanes and the risk of water erosion increases (Zink et al., 2011). Compacted soil cannot fully provide basic environmental components and maintain the diversity of soil life (Lees et al., 2016). Therefore, compaction has agricultural, environmental and economic consequences. Compaction causes changes in the water and air regimen and also has a negative effect on the plant root system. The intake of water and nutrients is limited and yields are reduced (Yahya et al., 2015). Compaction can also make nitrogen fertilizers less effective (Tullberg, 2010). Soil compaction is one of the most damaging factors which reduce the potential of agricultural productivity (Bengough et al., 2011).

(C) 2021 Institute of Agrophysics, Polish Academy of Sciences (c) (1) (-) $\Theta$ 
Compaction affects the soils used to grow every grain composition, the main influence is the representation of the clay fraction (Antille et al., 2016). On the other hand, a high content of organic carbon can increase resistance to deformation, and increase elasticity. It can even reduce degree of compactness of very heavy soil. The influence of the level of soil moisture during the period of tractor related compaction is also very relevant (Nawaz et al., 2013).

In the Czech Republic, about $49 \%$ of the total area of arable land is at risk; an estimated $70 \%$ of this risk is due to technological compaction (Ministry of Agricultural, 2015). Globally, around 68 million ha of agricultural land has been degraded by compaction (Flowers and Lal, 1998). Most often, compaction occurs at a depth of between 0.3 and $0.4 \mathrm{~m}$, this may be attributed to the fact that at this depth compaction is not influenced by the use of agricultural machinery, such as deep ploughing. However, the highest soil tension is observed in the lower part of the topsoil between 0.1 and $0.2 \mathrm{~m}$ (Neugschwandtner et al., 2020).

The resulting magnitude of soil property changes is affected by the size of the axle load, which is directly proportional to tyre inflation, contact pressure, contact surface size and soil moisture content. It is indirectly proportional to the initial bulk density, traveling speed of the tractor and the number of travel passes. Repeated traveling accumulates compaction and their influence lessens with each additional pass. Even the first travel passes can cause 75 to $80 \%$ of the total changes (Botta et al., 2008). However, each soil reacts differently to the passage of agricultural machinery. There are known results obtained when soil with a normal operating moisture negatively responded to a tyre pressure of less than $30 \mathrm{kPa}$, while in other cases more than $240 \mathrm{kPa}$ did not cause any damage (Davies et al., 1972). Surface compaction is also influenced by soil type and by the sowing process (Mosaddeghi et al., 2000).

The aim of this paper is to compare the influence of various tyre pressures (200 and $100 \mathrm{kPa}$ ) on selected physical properties of the soil, namely bulk density, porosity and the range in pore-size distribution, aeration and minimal air capacity. Assessing these parameters makes it possible to determine whether the soil is at risk of compaction. Differences in these characteristics were also evaluated between the zero variant (no travel) and individual variants in pressure. We carried out the experiment in field conditions, that is, under natural soil deposition.

\section{MATERIAL AND METHODS}

Field measurements were carried out at the end of October 2015 on the plot south of the village of Otmarov, southern Moravia, in the Czech Republic, (192.99 m above sea level, zero slope, soil type phaeozem, with a carbon content of $1.59 \%$ in the layer $>0.3 \mathrm{~m}$ and $0.46 \%$ lower in the layer $<0.3 \mathrm{~m}$ ). The plot is used as arable land by a private farmer. The farmer had been using a minimized treatment (treatment without ploughing) of the soil on the plot for a long period of time (for 8 years).

According to world classification standards, the soil ranks among the phaeozems (IUSS Working Group WRB, 2015). In terms of physical and chemical soil properties, this soil type may be described as very fertile. The grain texture of the plot and the moisture level during sampling for the measured depths are given in Tables 1 and 2.

The plot had been used as arable land for crop cultivation for a long period of time by a private farmer. The crop rotation used alternates winter wheat and common sunflower. In 2015, winter wheat was grown. The harvest took place during July. Straw was crushed and evenly distributed over the surface. In July, stubble tillage was performed using a heavy plate cultivator to a depth of $0.1 \mathrm{~m}$. During September, the soil was further treated with a short plate cultivator to a depth of $0.12 \mathrm{~m}$.

In order to test the effect of different tyre pressures on causing changes to the soil properties, we have chosen the Deutz-Fahr, Agrotron X720 tractor. The front three-point hitch was fitted with weights while the rear three-point hitch was fitted with a carried plate cultivator. The total weight of the machine was $14750 \mathrm{~kg}$ (front wheels weight: $2990 \mathrm{~kg}$, rear wheels weight: $11760 \mathrm{~kg}$ ). The size of the front tyres was $600 / 65 \mathrm{R} 38$ and the size of the rear tyres was 710/70R42 (Michelin AXIOBIB tyres with "Tractor Pattern R1"). The tyres were radial with a directional arrow design.

The inflation pressure ranged from 200 to $100 \mathrm{kPa}$. The tyres were typically operated under a pressure of $200 \mathrm{kPa}$. The low inflation pressure of $100 \mathrm{kPa}$ was chosen with reference to the tyre manufacturer's recommendations. The experiment was carried out on a flat part of the plot. The tractor travel speed through the test plot was approximately $2.8 \mathrm{~m} \mathrm{~s}^{-1}$. In order to determine changes in the physical properties of the soil due to the passage of the tractor with different working tyre pressures, intact soil core samples

Table 1. Grain texture of the plot, average values with standartd deviation $( \pm \mathrm{SD})$

\begin{tabular}{lccc}
\hline $\begin{array}{l}\text { Particle size distribution } \\
\text { soil depth } 0-0.3 \mathrm{~m}\end{array}$ & Value (wt. \%) & $\begin{array}{c}\text { Particle size distribution } \\
\text { soil depth } 0.3-0.5 \mathrm{~m}\end{array}$ & Value (wt. \%) \\
\hline Clay $(<2) \mu \mathrm{m}$ & $34.77( \pm 1.89)$ & Clay $(<2) \mu \mathrm{m}$ & $46.41( \pm 1.59)$ \\
Silt $(50-2) \mu \mathrm{m}$ & $34.25( \pm 1.41)$ & Silt $(50-2) \mu \mathrm{m}$ & $40.84( \pm 2.66)$ \\
Sand $(2000-50) \mu \mathrm{m}$ & $30.98( \pm 1.64)$ & Sand $(2000-50) \mu \mathrm{m}$ & $12.75( \pm 4.25)$ \\
\hline
\end{tabular}

wt. \% - weight percent. 
Table 2. Soil moisture during experiment; average values with standartd deviation $( \pm \mathrm{SD})$

\begin{tabular}{cc}
\hline Depth $(\mathrm{m})$ & Moisture $($ vol. \%) \\
\hline $0-0.1$ & $24.61( \pm 1.53)$ \\
$0.1-0.2$ & $33.39( \pm 0.39)$ \\
$0.2-0.3$ & $31.69( \pm 0.39)$ \\
$0.3-0.4$ & $32.58( \pm 0.83)$ \\
$0.4-0.5$ & $32.94( \pm 1.26)$ \\
\hline
\end{tabular}

were collected using a $100 \mathrm{~cm}^{3}$ Kopecký cylinder. The collection of intact soil core samples was carried out at depths of 0 to $0.5 \mathrm{~m}$ in steps of $0.1 \mathrm{~m}$. Due to the irregular soil compaction caused by the tyre pattern, the first soil core samples were taken in $0.05 \mathrm{~m}$. In order to determine the changes caused by the passage of the tractor, the core samples were taken in the track, namely in the centre of the tyre imprint, and midway between the tracks for each passage, with the effects of different tyre pressures being determined separately (zero variant). For all variants, four core soil samples were taken for each depth (each monitored a physical parameter which was determined four times for each depth at a given tyre inflation pressure). The sampling site positions are shown in Fig. 1.

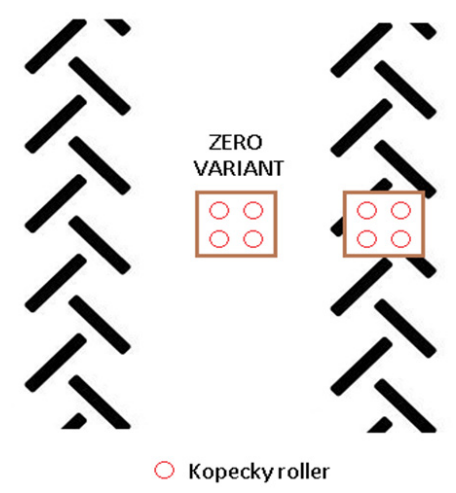

Fig. 1. Position of soil sampling using the Kopecký cylinder.

Undisturbed core soil samples were subsequently processed according to a valid methodology (Arshad and Coen, 1992) in the laboratory. The undisturbed soil samples (Kopecký cylinder) were saturated on glass covered by a filter paper with continuous tap water delivery. In the next step, $72 \mathrm{~h}$ later, the fully saturated soil samples were placed on the dry filter paper (4 layers) to monitor their water holding capability. The water holding capability was measured at selected times by sample weighing (after saturation, 0.5 , 1,2 and $24 \mathrm{~h}$ after full saturation); each sample was put on a new pack of dry filter paper sheets after weighing. After the final weighing, the samples were dried at $105^{\circ} \mathrm{C}$ to a constant weight and then weighed again. The values from the weighing of the samples were used to calculate the bulk density, total porosity, capillary volumes (slowly draining pores and water holding pores), semicapillary (transition between capillary and non-capillary pores) and noncapillary pores (rapidly draining pores), minimal air capacity and aeration (using formulas). All of these properties were determined in order to assess the impact of tractor travel at different tyre pressures.

The principal component analysis (PCA) was used to determine the relationships between the monitored physical properties with respect to the different tyre pressures of the traveling tractor. For the two principal components, a chart of the component weights was created together with a scatter diagram of the component score.

An ANOVA together with Tukey's multiple comparison test was used to determine the statistical differences in the values of the monitored physical properties of the soil for each depth with respect to tyre pressures. The confidence level was set to $* p<0.05$. Before ANOVA testing, all preconditions (mentioned in Meloun and Militký, 2012) were verified.

All statistical operations were performed using Statistica 12 (StatSoft, USA).

\section{RESULTS AND DISCUSSION}

For the PCA, we have selected the first two components, which explains $97.23 \%$ of the information, or the overall variability in the data. We can see the result in Fig. 2. Here we may observe the correlation and identify the sampling points with the greatest change in the monitored physical soil properties. It is clear from this graph that the biggest changes occurred at the shallowest depth. With increasing depth, the differences between the variants decreased with pressure. The depth of 0.2 to $0.3 \mathrm{~m}$ is an exception. However, this may be due to the possible formation of a phenomenon commonly known as the plough pan which forms as a result of long-term minimization treatment (treatment without ploughing) of the plot, to a depth of $0.2 \mathrm{~m}$.

We have found a statistically significant negative correlation $(* * p<0.01)$ between changes in the bulk density and the total porosity $(\mathrm{R}=-0.995)$. This relationship was confirmed by Assouline (2006) who modelled the relationship between the bulk density and the water retention curve. At the same time, with decreasing total porosity, aeration also decreases, this has a high degree of correlation with the semicapillary pores. The minimal air capacity that correlates closely with the noncapillary pores value (0.996), is also closely related (increases or decreases) with aeration (0.967). After the passage of agricultural machinery, namely with the increase in bulk density, the air spaces are filled with soil, which leads to the expulsion of air. This results in the reduced mechanical stability of the soil (Ressia et al., 1998). A weaker correlation was found, in particular, between the water retention capacity and the capillary pores and bulk density (correlation 0.742 ) and total porosity (correlation 0.737). 


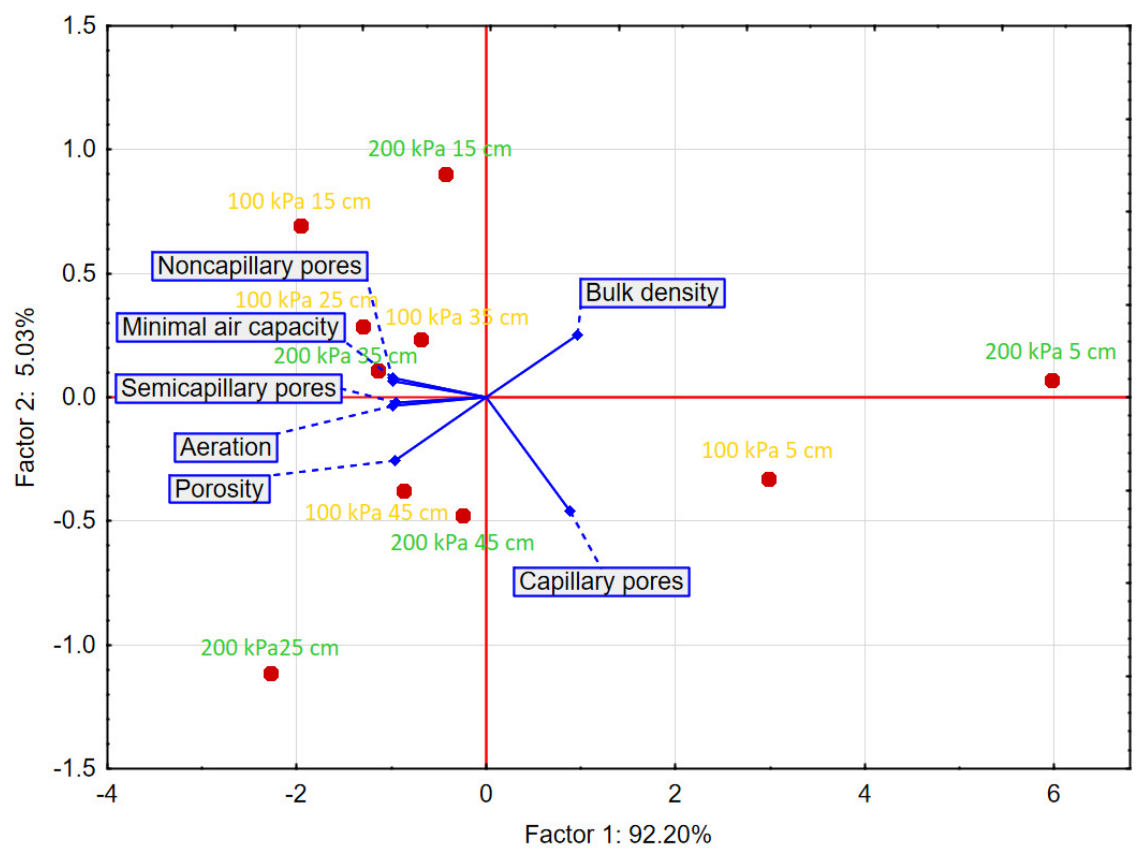

Fig. 2. Graph of the component weights with a scatter plot of the component score, the red points represent individual soil samples (the samples are distributed according to their evaluated physical properties on the graph).

Figure 2 also shows that the largest change occurred at a depth of 0 to $0.1 \mathrm{~m}$ and at an inflation pressure of $200 \mathrm{kPa}$, where the bulk density change was most evident with reduced total aeration and semicapillary pores. Significant changes $(* * \mathrm{p}<0.01)$ were also observed in the noncapillary pores and minimal air capacity. At a pressure of $100 \mathrm{kPa}$, the greatest changes also occurred at a 0 to $0.1 \mathrm{~m}$ depth. At other depths, the changes were not so significant for either pressure.

Due to the interconnection of aeration and porosity, we decided not to analyse the aeration values further.

We used the Tuckey's test, which was a part of ANOVA, to assess changes in the physical soil properties induced by different tyre pressures at individual depths.

Figure 3 shows changes in the dry bulk density values. The bulk density value reflects the ratio of the solid portions of soil and porosity, thus indicating the looseness or compactness of the soil. Figure 3 shows the statistically significant change due to travel at a depth of 0 to $0.1 \mathrm{~m}$. For a tyre pressure of $200 \mathrm{kPa}$, the value of the bulk density increased by 368 to $1401 \mathrm{~kg} \mathrm{~m}^{-3}$ (value obtained in the track - position B) and for $100 \mathrm{kPa}$ it increased by 209 to $1376 \mathrm{~kg} \mathrm{~m}^{-3}$ (value obtained by measuring in the track - position B). According to the bulk density of the soil sample we can also evaluate the physical condition of the soil. For the clay loam soil in the Czech Republic, the limit value is $1400 \mathrm{~kg} \mathrm{~m}^{-3}$. If it is higher, the physical condition of these soils is categorized as unsatisfactory (Pokorný et al., 2007; Grečenko, 2016).
In the case of tractor travel with a tyre pressure of $200 \mathrm{kPa}$, the density at the first depth reached the limit of when we could evaluate the physical condition of the soil as damaged.

Changes in values above $100 \mathrm{~kg} \mathrm{~m}^{-3}$ were found at an inflation pressure of $200 \mathrm{kPa}$ and at a depth of 0.1 to $0.2 \mathrm{~m}$. However, this change was not statistically significant. At a pressure of $100 \mathrm{kPa}$ and depths greater than $0.1 \mathrm{~m}$, there were no significant changes in bulk density that could be attributed to the passage of the tractor.

The difference in the bulk density between the pressures (between the pressures measured out of the track - position A) used was most obvious at a depth of 0 to $0.1 \mathrm{~m}$, where the values varied by $133 \mathrm{~kg} \mathrm{~m}^{-3}$. However, a statistically significant difference in pressure values was not found.

Moreover, for both pressure variants a significant exceedance of the critical bulk density at depths of 0.1 to $0.2 \mathrm{~m}$ and 0.2 to $0.3 \mathrm{~m}$ may be observed. This condition may be caused by plot treatment without ploughing, as the local farmer had been using the minimized treatment of soil for 8 years. A more pronounced deterioration of physical properties due to the total or partial abandonment of ploughing has already been mentioned by Carter (1990). Compaction in uncultivated soils or soils with limited treatment has also been mentioned in Llewellyn et al. (2009). At greater depths, the value of the bulk density decreases, but it is still around the critical value for assessing the physical condition of the soil in terms of bulk density. According to similar values at a depth of 0.1 to $0.3 \mathrm{~m}$ we may assume the creation of the phenomenon widely known as the 

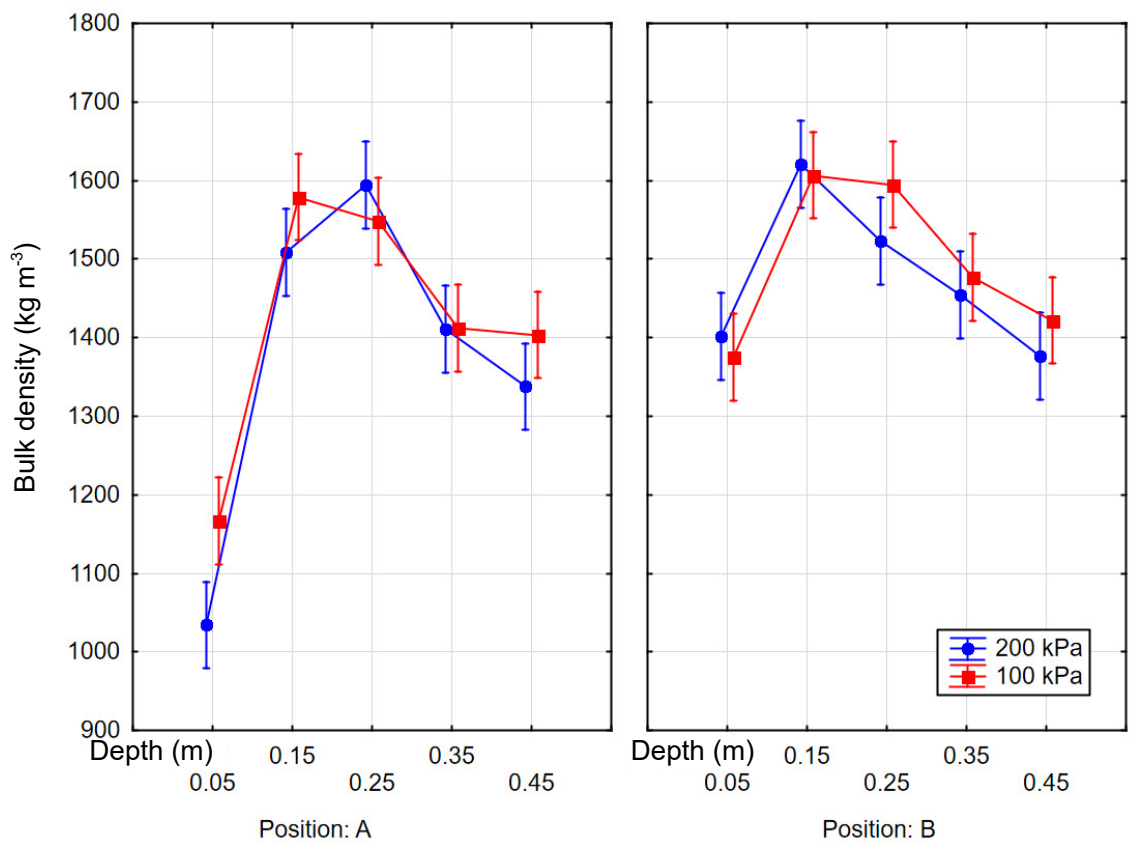

Fig. 3. Results of a single-factor ANOVA for dry bulk density. The vertical error bars indicate a $95 \%$ confidence interval for the mean (depth values are presented as the centre values of the measured ranges). Position A: values obtained out of the track, Position B: values obtained in the track).

plough pan. This is the location where compaction accumulates. Its depth then depends on the ploughing depth. Under field conditions, an experiment was carried out to compact the soil depending on the depth of treatment in the two soil types, namely sandy loam and loam. Minimized processing was negatively manifested in the loam, when accumulation occurred at depths of 0.16 to $0.24 \mathrm{~m}$ after the first year of the experiment and at 0.14 to $0.28 \mathrm{~m}$ in the second year of the experiment. By contrast, the sandy loam showed a deeper plough pan, from a depth of $0.4 \mathrm{~m}$. This result suggests that the formation depth depends on the grain composition of the soil, namely the fine particle content. Our plot is classified as a clay loam category, therefore it corresponds more to the results found on the plot with the clay soil.

The figure of total porosity is not given due to the very high (negative) correlation with the bulk density. Therefore, a statistically significant difference was found at a depth of 0 to $0.1 \mathrm{~m}$, when, at a pressure of $200 \mathrm{kPa}$ the porosity decreased by $13.6 \%$ (from 60.07 to $46.49 \%$ ) and at a pressure of $100 \mathrm{kPa}$ by $7.7 \%$ (from 54.77 to $47.09 \%$ ). Also, as with the bulk density, no statistically significant changes were found at greater depths due to the passage of the tractor with different tyre pressures. The critical value for the porosity of our soil type is set at $47 \%$ (Pokorný et al., 2007; Grečenko, 2016). At this value, the soil is physically damaged. As with bulk density, the first depth at both pressures was in terms of the critical value at the boundary, so again, the negative influence of the passage with the zero variant was confirmed. At a depth of 0.1 to $0.3 \mathrm{~m}$, the critical value was exceeded in all variants, at other depths the porosity grew and ranged more or less around the limit value.
Radford et al. (2000) also point to a major change in the total porosity caused by the passage of agricultural machinery at the upper $0.2 \mathrm{~m}$ of wet vertisol. All pore sizes were negatively affected. Tarawally et al. (2004) observed a significant increase in capillary pore volume at the expense of semicapillary and noncapillary ones. This leads to a deterioration in the hydraulic capacity of the soil.

Figure 4 shows a pore-distribution graph. This graph shows the absolute changes between the values measured in the track and the values measured outside the track for the monitored pore types at the respective depth at a given pressure.

Figure 4 shows that larger changes occur after the passage of the tractor with an inflation pressure of $200 \mathrm{kPa}$. And that applies both to the increased presence of capillary pores and the decreased presence of semicapillary and capillary pores. For both pressure variants, the changes to the noncapillary pores were most distinct, but for the $200 \mathrm{kPa}$ variant this change is more pronounced. However, the influence of the inflation pressure cannot be classified as statistically significant $\left({ }^{*} p>0.05\right)$. The values of the average relative changes for individual pores are shown in Table 3, where values outside the track are assumed to be $100 \%$.

As shown in Fig. 4 and Table 3, both variants showed a significant increase in the capillary pores that are the finest ones at the most shallow depth. By contrast, the presence of semicapillary and noncapillary pores ensure that the gravitational motion of water in the soil decreased. Yahya et al. (2011) proved in their long-term experiment that the passage of machinery has a great effect on the occurrence 

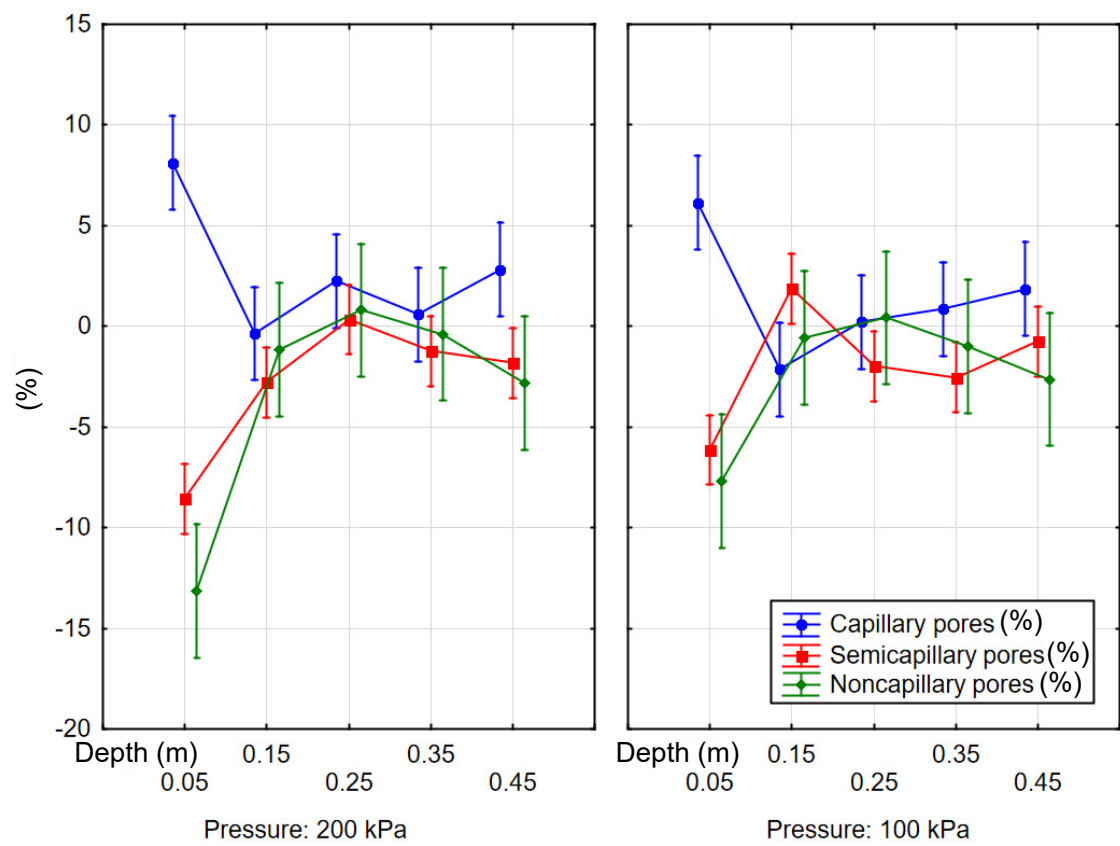

Fig. 4. Results of a single-factor ANOVA for absolute pore changes at a given inflation pressure. The vertical error bars indicate $95 \%$ confidence intervals for the mean (the depth values are given as the centre values of the measured ranges).

Table 3. Values of average relative changes for individual pores

\begin{tabular}{cccc}
\hline \multirow{2}{*}{$\begin{array}{c}\text { Depth } \\
(\mathrm{m})\end{array}$} & \multicolumn{3}{c}{ Pores $(\%)$} \\
\cline { 2 - 4 } & Capillary & Semicapillary & Noncapillary \\
\hline \multicolumn{3}{c}{ Pressure $200 \mathrm{kPa}$} \\
0.15 & 26.9 & -67.2 & -77.5 \\
0.25 & -1.0 & -52.7 & -20.7 \\
0.35 & 1.7 & 15.4 & 186.2 \\
0.45 & 8.3 & -16.2 & -4.4 \\
& & -28.6 & -27.8 \\
0.05 & 19.6 & -55.3 & -57.2 \\
0.15 & -6.6 & 48.7 & 14.6 \\
0.25 & 0.8 & -34.1 & 49.3 \\
0.35 & 2.7 & -29.2 & -13.8 \\
0.45 & 5.7 & -8.8 & -29.0 \\
\hline
\end{tabular}

of individual pores, namely that there is a negative development in the presence of semicapillary and noncapillary pores in comparison with capillary ones. However, they only focused on the upper $0.1 \mathrm{~m}$. Destain et al. (2016) recorded the largest changes in porosity caused by the passage of agricultural machinery at a depth of 0.07 to $0.25 \mathrm{~m}$ in the luvisol type. Noncapillary pores were more affected than semicapillary pores. In the subsoil the changes did not reach such high values and were found mainly in noncap- illary pores. In our case, however, at both pressures and at a depth of 0.2 to $0.3 \mathrm{~m}$, we recorded practically zero or only very small changes in the values of all pore sizes both before and after the passage of the tractor. This suggests the presence of a plough pan where the soil is already so compacted that the influence of farm machinery is no longer reflected in the change of the pore-size distribution. At higher pressure there was an increase in the proportion of capillary pores, while at lower pressure, there was a decrease in the proportion of semicapillary pores. At greater depths, the formation of fine pores occurred at the expense of noncapillary and semicapillary pores. Disagreement with the results from Destain et al. (2016) may be affected by the prevailing moisture conditions at the time at which the experiment was carried out (the agrotechnical interventions on the plot were performed under higher moisture levels than appropriate). However, the researchers have stated that they chose this in view of the normal agricultural practices used in their country. Arvidsson and Keller (2007) stated in their long-term compaction experiment that the compaction induced by the passage of agricultural machinery reduces the effective pore diameter as well as their count per area of soil plot, but in contrast, their tortuosity increases.

Figure 5 shows a change in the minimal air capacity value. This value is affected by the presence of noncapillary pores in the total porosity. For arable soils, its critical value is recommended to be $10 \%$ (Hall et al., 1977). Soil condition below this value causes plant root damage through a lack of oxygen, resulting in reduced activity. The diagram shows that sufficient aeration only occurred at a depth of 0 to $0.1 \mathrm{~m}$ before the passage of machinery. This may be 

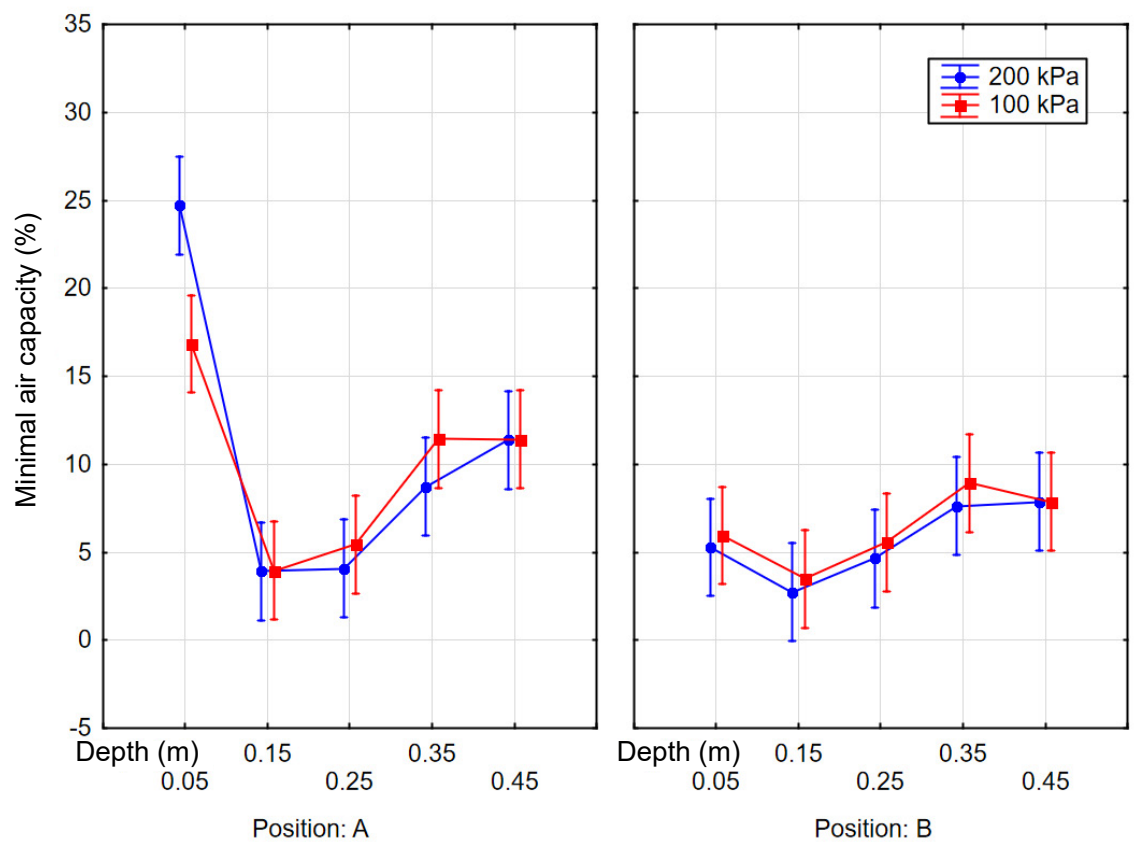

Fig. 5. Results for a single-factor ANOVA with a minimal air capacity. Vertical error bars indicate $95 \%$ confidence intervals for the mean (depth values are given as the centre values of the measured ranges; Position A: values obtained out of the track, Position B: values obtained in the track).

attributed to the loosening of the topsoil after the harvesting of the crop in the year of the on-going experiment. However, at depths of 0.1 to $0.2 \mathrm{~m}$ and 0.2 to $0.3 \mathrm{~m}$, we may observe the unfavourable physical condition of the soil, even in the case of the zero variant. Again, this may be explained by the long-term cultivation of the plot and not disturbing the hardened layer through deep treatment. However, from a depth of $0.3 \mathrm{~m}$, it is possible to observe a better condition of minimal air capacity for both zero variants and the same value or a worsening one after the passage of machinery. This condition may not be directly caused by the impact of farm machinery, but by the natural variability of the soil environment. Moreover, the statistically significant differences in the changes were not described by any variant of tyre inflation.

From the point of view of the statistical significance of the influence of tyre inflation pressure, the statistical significance at the $95 \%$ level was only demonstrated at a depth of 0 to $0.1 \mathrm{~m}$. At a pressure of $100 \mathrm{kPa}$, the minimal air capacity was reduced to $6 \%$ (from the original $16.8 \%$ ) and at a pressure of $200 \mathrm{kPa}$ it was reduced to $5.3 \%$ (from the original $24.7 \%$ ). At other depths, statistically significant changes were not found (Fig. 5).

Our results indicate that for most of the described physical properties of the soil, a statistically significant change in the values induced by the passage of agricultural equipment only occurred at the first depth of 0 to $0.1 \mathrm{~m}$. The other depths did not show any significant changes even with regard to the different working pressure of the tractor tyres. Singh et al. (2015) has stated that just below a depth of $0.1 \mathrm{~m}$, a compact surface layer is created that can extend up to a depth of $40 \mathrm{~cm}$.

Abu-Hamdeh (2003) reported that with increasing tyre pressures, greater depths are affected. In our case, this did not apply. This may be due to the factors mentioned above, which is the possibility of a compacted layer being formed, as was also indicated by the porosity results in Fig. 4 and, above all, by the low moisture conditions during the experiment. In contrast, the results of Arvidsson and Keller (2007) were confirmed, when they compared the soil stress caused by the passage of equipment at different tyre pressures and loads on a soil classified by grain size as loam. The greatest negative changes occurred at maximum inflation, namely at $150 \mathrm{kPa}$. However, the main differences occurred at a depth of up to $0.1 \mathrm{~m}$. At greater depths, namely $0.3 \mathrm{~m}$ and deeper, there were no significant differences in soil stress with respect to tyre pressure. At these locations, it was rather the overall equipment load that made the difference. They stated that below that depth the tyre pressure parameter does not have much significance.

However, Arvidsson and Keller (2007) also point out that soil stress is not a simple function of tyre pressure or machine load. It is also a function of the tyre-soil relationship and depends on the tyre pressure, the load, as well as on the soil properties and its condition. 


\section{CONCLUSIONS}

1. The most significant changes to physical properties caused by the passage of agricultural machinery were only reflected at the first monitored depth of 0 to $0.1 \mathrm{~m}$. The passage of the tractor at both tyre pressures studied caused an increase in bulk density and a reduction in both total porosity and minimal air capacity. As far as pore distribution is concerned, the presence of capillary pores increased, while the presence of noncapillary and semicapillary pores decreased.

2. At greater depths, significant changes in physical properties were not recorded for any of the variants, thereby indicating the presence of a plough pan. This phenomenon is one of the global trends in the degradation of agricultural land due to the use of mechanical farm equipment. The results of the measurements indicate that plough pans develop near the surface at 0.1 to $0.3 \mathrm{~m}$, which adversely affects the cultivated crops. They can also adversely affect the intake of rainfall water during torrential rains and result in substantial soil erosion during the rain. The presence of a plough pan (on the experimental plot) is most likely the result of long-term minimization treatment (treatment without ploughing) of the plot.

3. In terms of tyre pressures, minor changes in the described physical properties occurred for the low tyre pressure study of $100 \mathrm{kPa}$. However, the differences between the variants were not statistically conclusive, with the exception of the minimal air capacity.

4. An interesting result of this study in practice would be to make recommendations concerning which tyre pressures to use in which moisture condition of the treated soil. Of course, this would have to be different for each soil as classified by grain size, the tyres used and the machinery load. Particular attempts to choose the appropriate tyres with respect to grain size composition are already taking place.

Conflict of interest: The authors declare no conflict of interest.

\section{REFERENCES}

Abu-Hamdeh N.H., 2003. Soil compaction and root distribution for okra as affected by tillage and vehicle parameters. Soil Till. Res., 74, 25-35. https://doi.org/10.1016/s0167-1987(03)00122-3

Antille L.D., Bennett J., and Jensen T., 2016. Soil compaction and controlled traffic considerations in Australian cottonfarming systems. Crop and Pasture Sci., 67, 1-28. https://doi.org/10.1071/cp15097

Arshad M.A. and Coen G.M., 1992. Characterization of soil quality: Physical and chemical criteria. Am. J. Alt. Agric., 7, 5-12.

Arvidsson J. and Keller T., 2007. Soil stress as affected by wheel load and tyre inflation pressure. Soil Tillage Res., 96, 284291. https://doi.org/10.1016/j.still.2007.06.012
Assouline S., 2006. Modeling the Relationship between Soil Bulk Density and the Water Retention Curve. Vadose Zone J., 5, 554-563. https://doi.org/10.2136/vzj2005.0083

Bengough A.G., McKenzie B.M., Hallett P.D., and Valentine T.A., 2011. Root elongation, water stress and mechanical impedance: a review of limiting stresses and beneficial root tip traits. J. Exp. Botany, 62, 59-68. https://doi.org/10.1093/jxb/erq350

Botta G.F., Rivero D., Tourn M., Bellora M.F., Pozzolo O., Nardon G., Balbuena R., Tolon-Becerra A., Rosatto H., and Stadler S., 2008. Soil compaction produced by tractor with radial and cross-ply tyres in two tillage regimes. Soil Till. Res., 101, 44-51. https://doi.org/10.1016/j.still.2008.06.001

Carter M.R., 1990. Relative measures of soil bulk density to characterize compaction in tillage studies on fine sandy loams. Can. J. Soil Sci., 70, 425-433. https://doi.org/10.4141/cjss90-042

Davies B., Eagle D., and Finney B., 1972. Soil Management, first ed. Ipswich, Farming Press Ltd.

Destain M.F., Roisin C., Dalcq A.S., and Mercatoris B.C.N., 2016. Effect of wheel traffic on the physical properties of a Luvisol. Geoderma, 262, 276-284. https://doi.org/10.1016/j.geoderma.2015.08.028

Flowers M.D. and Lal R., 1998. Axle load and tillage effects on soil physical properties and soybean grain yield on a mollic ochraqualf in northwest Ohio. Soil Till. Res, 48, 21-35. https://doi.org/10.1016/s0167-1987(98)00095-6

Grečenko A., 2016. Tire compaction capacity rating on nonstandard soil. J. Terramechanics, 66, 59-61. https://doi.org/10.1016/j.jterra.2016.03.003

Hall D.G.M., Reeve M.J., Thomasson A.J., and Wright V.F., 1977. Water retention, porosity and density of field soils. Soil Survey of England and Wales Technical Monograph No. 9. Rothmansted Experimental Station, Harpenden, Herts., UK.

IUSS Working Group WRB, 2015. World Reference Base for Soil Resources 2014, update 2015. International soil classification system for naming soils and creating legends for soil maps. World Soul Resources Reports No. 106. FAO, Rome. https://doi.org/10.1007/springerreference_76722

Keller T., Sandin M., Colombi T., Horn R., and Or D., 2019. Historical increase in agricultural machinery weights enhanced soil stress levels and adversely affected soil functioning. Soil Til. Res., 194, 1-12. https://doi.org/10.1016/j.still.2019.104293

Lees K.J., McKenzie A.J., Newell Price J.P., Critchley C.N., Rhymer C.M., and Whittingham M.J., 2016. The effects of soil compaction mitigation on below-ground fauna: How earthworms respond to mechanical loosening and power harrow cultivation. Agric., Ecosyst. Environ., 232, 273282. https://doi.org/10.1016/j.agee.2016.07.026

Llewellyn R.S., D'Emden F., and Gobbett D., 2009. Adoption of no till and conservation farming practices in Australian grown grain growing regions: current status and trends. Preliminary report, to Conservation Agriculture Alliance in Australia and New Zealand. CSIRO Sustainable Ecosystems, Adelaide.

Meloun M. and Militký J., 2012. Interactive statistical data analysis (in Czech). Praha, Karolinum, Charles University in Prague. 
Ministry of Agricultural, 2015. Situational and prospective report - soil (in Czech). Department of Agricultural Economics and Information.

Mosaddeghi M.R., Hajabbasi M.A., Hemmat A., and Afyuni M., 2000. Soil compactibility as affected by soil moisture content and farmyard manure in central Iran. Soil Till. Res., 55, 87-97. https://doi.org/10.1016/s0167-1987(00)00102-1

Nawaz M.F., Bouriié G., and Trolard F., 2013. Soil compaction impact and modelling. A review. Agron. Sustain. Develop., 33, 291-309.

Neugschwandtner R.W., Száková J., Pachtrog V., Tlustoš P., Černý J., Kulhánek M., Kaul H.P., Euteneuer P., Moitzi G., and Wagentristl H., 2020. Basic soil chemical properties after 15 years in a long-term tillage and crop rotation experiment. Int. Agrophys., 34(1), 133-140. https://doi.org/10.31545/intagr/114880

Pokorný E., Šarapatka B., and Hejátková K., 2007. Evaluation of soil quality in ecological farming company (in Czech). ZERA - Agricultural and Environmental Regional Agency, o.s.

Radford B.J., Bridge B.J., Davis R.J., McGarry D., Pillai U.P., Rickman J.F., Walsh P.A., and Yule D.F., 2000. Changes in the properties of a Vertisol and responses of wheat after compaction with harvester traffic. Soil Till. Res., 54, 155170. https://doi.org/10.1016/s0167-1987(00)00091-x

Raper R.L., 2005. Agricultural traffic impacts on soil. J. Terramech., 42, 259-280.

https://doi.org/10.1016/j.jterra.2004.10.010
Ressia J.M., Mendivil G., Balbuena R.H., and Chidichimo O., 1998. Root growth and grain yield of corn in relation to tillage systems. Proc. IV CADIR, Argentine Congress on Agricultural Engineering, September, Rosario, Argentina.

Singh J., Salaria A., and Kaul A., 2015. Impact of soil compaction on soil physical properties and root growth: A review. International J. Food Agric. Vet. Sci., 5(1), 23-32.

Tarawally M.A., Medina H., Frómeta M.E., and Itza C.A., 2004. Field compaction at different soil-water status: effects on pore size distribution and soil water characteristics of a Rhodic Ferralsol in Western Cuba. Soil Till. Res., 76, 95-103. https://doi.org/10.1016/j.still.2003.09.003

Tullberg J., 2010. Tillage, traffic and sustainability - A challenge for ISTRO. Soil Till. Res., 111, 26-32.

https://doi.org/10.1016/j.still.2010.08.008

Yahya Z., Husin A., Talib J., Othman J., Darus S.Z., Ahmed A.H., and Jalloh M.B., 2011. Pores reconfiguration in compacted Bernam series soil. Am. J. Applied Sci., 8, 212216. https://doi.org/10.3844/ajassp.2011.212.216

Yahya Z., Zulkifli H., Haniff M.H., Nur Zuhaili H.A.Z.A., Nordiana A.A., Shuib A.R., Afifah A.R., and Nur Maisarah J., 2015. Alterations of soil physical properties due to mechanization activities under oil palm on Bernam series soil. Int. J. Agric. Innov. Res., 3, 1435-1446.

Zink A., Fleige H., and Horn R., 2011. Verification of harmful subsoil compaction in loess soils. Soil Till. Res., 114, 127134. https://doi.org/10.1016/j.still.2011.04.004 